\title{
Random Herd Curves in a Test-Day Model for Milk, Fat, and Protein Production of Dairy Cattle in The Netherlands
}

\author{
A. P. W. de Roos, A. G. F. Harbers, and G. de Jong \\ NRS, 6800 AL Arnhem, The Netherlands
}

\section{ABSTRACT}

With random regression models, genetic parameters of test-day milk production records of dairy cattle can be estimated directly from the data. However, several researchers that used this method have reported unrealistically high variances at the borders of the lactation trajectory and low genetic correlations between beginning and end of lactation. Recently, it has been proposed to include herd-specific regression curves in the random regression model. The objective was to study the effect of including random herd curves on estimated genetic parameters. Genetic parameters were estimated with 2 models; both included random regressions for the additive genetic and permanent environmental effect, whereas the second model also included a random regression effect for herd $\times 2$-yr period of calving. All random regressions were modeled with fourth-order Legendre polynomials. Bayesian techniques with Gibbs sampling were used to estimate all parameters. The data set comprised 857,255 test-day milk, fat, and protein records from lactations 1,2 , and 3 of 43,990 Holstein cows from 544 herds. Genetic variances estimated by the second model were lower in the first $100 \mathrm{~d}$ and at the end of the lactation, especially in lactations 2 and 3. Genetic correlations between d 50 and the end of lactation were around 0.25 higher in the second model and were consistent with studies where lactation stages are modeled as different traits. Subsequently, estimated heritabilities for persistency were up to 0.14 lower in the second model. It is suggested to include herd curves in a random regression model when estimating genetic parameters of test-day production traits in dairy cattle.

(Key words: random regression, herd curve, test-day production, dairy cattle)

Abbreviation key: HTD = herd test date, VCE-HC = model for analysis including random herd curves, VCEnoHC = model for analysis excluding random herd curves.

Received February 24, 2003.

Accepted March 14, 2004.

Corresponding author: S. de Roos; e-mail: Roos.S@cr-delta.nl.

\section{INTRODUCTION}

In the Interbull international genetic evaluation for dairy production traits of August 2003, 7 evaluation centers submitted predicted breeding values for bulls from a test-day model analysis, of which 5 evaluation centers (Belgium [Walloon territory], Canada, Finland, Germany [jointly with Austria], and The Netherlands [jointly with the Flemish part of Belgium]) used a random regression model (Interbull, 2003). Several other countries are developing a random regression test-day model and will implement it in their national genetic evaluation in the coming years. The implementation requires accurate genetic parameters that describe the covariance structure of test-day production records within and across lactations. Numerous researchers have reported estimates of genetic parameters for testday milk production traits using various models. The most popular methods have been random regression models, where the covariances among random regression coefficients are estimated directly from the data (Jamrozik et al., 1998; Jakobsen et al., 2002; Samoré et al., 2002), and indirect methods, where production records from different lactation stages are analyzed in a multi-trait evaluation and a covariance function is fitted to the covariance matrices (Lidauer et al., 2000; Gengler et al., 2001; Emmerling et al., 2002). Studies using random regression models often gave larger variances at the borders of the lactation and lower genetic correlations within lactation than those estimated in multi-trait studies (Van der Werf et al., 1998; Rekaya et al., 1999). The increase in estimated variances at the beginning and end of lactation in random regression models was often more apparent in second and third lactation than in first lactation (Jamrozik et al., 1997b; De Roos et al., 2001). It can be debated whether parameters from multi-trait studies should be taken as a reference to validate random regression models, especially because the herd $\times$ test date effect is often not modeled in multi-trait models. However, the extreme increases in genetic and permanent environmental variance at the periphery of the lactation that have been estimated with random regression models are widely regarded as unrealistic and in conflict with variances of phenotypic test-day production records. A major improvement to 
random regression models was to also model the permanent environment as a random regression, which resulted in less extreme variances and higher genetic correlations within lactation (Rekaya et al., 1999; Kettunen et al., 2000). Additional suggestions for improvement were to include only complete lactations in parameter estimation (Pool and Meuwissen, 2000), to account for heterogeneous residual variances across lactation (Olori et al., 1999), and to use appropriate mathematical functions for the random regression (Guo and Schaeffer, 2002; Jamrozik and Schaeffer, 2002).

The inclusion of herd-specific regression curves, either fixed or random, has been proposed by Gengler and Wiggans (2001) and Jamrozik et al. (2001). Gengler and Wiggans (2001) included the effect of herd $\times 2$-yr period of calving as a third random regression effect in addition to the additive genetic and permanent environmental effects in a random regression model for first lactation test-day milk production. The estimated variance of the random herd curves was 12 and $7 \%$ of the phenotypic variance at the beginning and end of the lactation, respectively, and negligible in midlactation. The use of random herd curves eliminated the increased estimated heritability at the beginning and end of the lactation. Jamrozik et al. (2001) included herd $\times$ year $\times$ season of calving as a fixed effect in the second stage of a hierarchical model for first lactation test-day milk production records. In a hierarchical model, phenotypic test-day production records are fitted via an appropriate lactation curve function as a first stage model with simultaneous modeling of the lactation curve coefficients as a second stage model. Inclusion of herd $x$ year $\times$ season in the second stage model accounted for the between-herd variation in shape of the lactation and resulted in more stable estimates of genetic variances throughout lactation, higher genetic correlations between production at extreme DIM, and lower heritabilities for persistency.

The objective of this study was to compare estimated genetic parameters for test-day milk, fat, and protein production in lactations 1,2 , and 3 for dairy cattle in The Netherlands using a random regression model, either with or without random herd curves.

\section{MATERIALS AND METHODS}

The data set was constructed from milk recording data of randomly selected herds from The Netherlands. Test-day milk, fat, and protein production records between DIM 5 and 335 of lactations 1, 2, and 3 were included, with age at calving between 22 and 34 mo, 33 and $52 \mathrm{mo}$, and 45 and $67 \mathrm{mo}$, respectively. Calving dates were between July 1990 and October 1999, and all cows had to have a first lactation. The calving date of the first lactation was required to be before July 1997 so that all cows had the opportunity to finish 3 lactations. Based on the results of Pool and Meuwissen (2000), lactations were required to have at least 6 testday records, of which one was before DIM 45 and one was after DIM 300. Herd test dates (HTD) were required to have at least 8 test-day records. All cows with production records had to be at least 50\% HolsteinFriesian, have 2 known parents, and at least 9 paternal half sibs. The final data set comprised 857,255 test-day milk, fat, and protein production records from 43,990 cows in 544 herds. The average (standard deviation) test-day production in lactations 1,2 , and 3 was 22.9 (5.2), 27.5 (8.0), and 29.0 (8.7) kg milk, 1010 (212), 1210 (315), and 1282 (355) g fat, and 795 (156), 960 (227), and 1006 (251) g protein, respectively. The pedigree contained 97,098 animals, including 474 bulls with lactating daughters. Animals with unknown parents were assigned to phantom groups based on their selection path, breed, country of origin, and birth year.

The data set was analyzed with 2 multi-lactation random regression test-day models, one with random herd curves (VCE-HC) and one without (VCE-noHC), in 3 single-trait runs for milk, fat, and protein. Model VCE-HC is

$$
\begin{aligned}
& \mathrm{y}_{\mathrm{ijklmnpd}}=\mathrm{ys}_{-} \mathrm{d}_{\mathrm{i}}+\text { page }_{-} \mathrm{d}_{\mathrm{j}}+\mathrm{pDIM}_{\mathrm{k}}+\mathrm{HTD}_{\mathrm{l}} \\
& +\sum_{\mathrm{q}=0}^{4} \mathrm{z}_{\mathrm{dq}} \mathrm{a}_{\mathrm{mpq}}+\sum_{\mathrm{q}=0}^{4} \mathrm{z}_{\mathrm{dq}} \mathrm{pe} \mathrm{mpq}_{\mathrm{mpq}} \\
& +\sum_{\mathrm{q}=0}^{4} \mathrm{z}_{\mathrm{dq}} \mathrm{h}_{\mathrm{npq}}+\mathrm{e}_{\mathrm{ijklmnpd}}
\end{aligned}
$$

where

$$
\begin{aligned}
& \mathrm{y}_{\mathrm{ijklmnpd}}=\text { test-day milk, fat, or protein production } \\
& \text { ys_ } d_{i}=\text { year } \times \text { season of calving } \times \text { class of DIM }
\end{aligned}
$$


Table 1. Number of Gibbs chains, total number of iterations, and minimum effective chain size for the variance component estimation of test-day milk, fat, and protein production using a model without (VCEnoHC) and with (VCE-HC) random herd curves.

\begin{tabular}{lrrrrrrrr}
\hline & \multicolumn{3}{c}{ VCE-noHC } & & \multicolumn{3}{c}{ VCE-HC } \\
\cline { 2 - 4 } \cline { 7 - 9 } Model trait & Milk & Fat & Protein & & Milk & Fat & Protein \\
\hline Gibbs chains, no. & 4 & 3 & 4 & & 7 & 8 & 8 \\
Total iterations, no. & 399,040 & 319,790 & 339,590 & & 386,160 & 486,670 & 448,810 \\
Iterations (excluding burn-in), no. & 299,040 & 244,790 & 239,590 & & 211,160 & 286,670 & 248,810 \\
Minimum effective chain size & 75 & 46 & 59 & & 90 & 110 & 98 \\
\hline
\end{tabular}

$$
\begin{aligned}
\mathrm{h}_{\mathrm{npq}}= & \text { herd curve effect of herd } \times 2 \text {-yr period of } \\
& \text { calving } \mathrm{n} \text { corresponding to polynomial } \mathrm{q} \text { of } \\
& \text { parity } \mathrm{p} \text {; and } \\
\mathrm{e}_{\mathrm{ijklmnpd}=} & \text { random residual belonging to observation } \\
& \mathrm{y}_{\mathrm{ijklmnpd}}
\end{aligned}
$$

The additive genetic covariance matrix among all animals was modeled as $\mathbf{A} \otimes \mathbf{K}_{\mathbf{a}}$, where $\mathbf{A}$ is the numerator relationship matrix, $\otimes$ depicts the Kronecker product operator, and $\mathbf{K}_{\mathbf{a}}$ is the $15 \times 15$ covariance matrix of the additive genetic regression coefficients. Phantom group effects were treated as fixed effects. The permanent environmental covariance matrix was modeled as $\mathbf{I} \otimes \mathbf{K}_{\mathbf{p}}$, where $\mathbf{I}$ is the identity matrix and $\mathbf{K}_{\mathbf{p}}$ is the 15 $\times 15$ covariance matrix of the permanent environmental regression coefficients. The herd curve covariance matrix was modeled as $\mathbf{I} \otimes \mathbf{K}_{\mathbf{h}}$, where $\mathbf{K}_{\mathbf{h}}$ is the $15 \times 15$ covariance matrix of the herd curve regression coefficients. Residuals were assumed uncorrelated between and within animals, with a constant variance within 10 DIM classes within parity (DIM 5 to 14,15 to 29, 30 to 49,50 to 79,80 to 109,110 to 154,155 to 199 , 200 to 244,245 to 289 , and 290 to 335 ). The other model, VCE-noHC, was the same model as VCE-HC, except that it did not include the random regression effect for herd $\times 2$-yr period of calving.

Parameters were estimated using a Bayesian analysis with Gibbs sampling. The algorithm was based on a Gauss-Seidel iterative BLUP scheme, as described by Janss and De Jong (1999). Uniform priors were assumed for all variance components. Residual variances were sampled from an inverted chi-square distribution, whereas $\mathbf{K}_{\mathbf{a}}, \mathbf{K}_{\mathbf{p}}$, and $\mathbf{K}_{\mathbf{h}}$ were sampled from an inverted Wishart distribution. More details about the parameter estimation are found in Pool et al. (2000). Burn-in and effective chain length were computed from transition probabilities using Gibanal (Van Kaam, 1998). Estimates of the variance components were calculated as posterior means of the stationary phase of the Gibbs chains.

Breeding values for 305-d production and persistency within lactation were computed as:

$$
\mathrm{BV}_{305 \mathrm{~d}}=\sum_{\mathrm{i}=5}^{305} \mathrm{BV}_{\mathrm{i}} \text { and } \mathrm{BV}_{\text {pers }}=\sum_{\mathrm{i}=61}^{305} \mathrm{BV}_{\mathrm{i}}-245 \times \mathrm{BV}_{60}
$$

where $\mathrm{BV}_{\mathrm{i}}$ is the predicted breeding value at DIM $\mathrm{i}$ (Jamrozik et al., 1997a). Overall 305-d production and persistency were computed by summing the lactation $\mathrm{BV}_{\mathrm{i}}$ with weight $0.41,0.33$, and 0.26 for lactation 1,2 , and 3, respectively (NRS, 2003). Genetic, permanent environmental, and herd curve variances of daily production, 305-d production, and persistency were computed as $\sigma^{2}=\mathbf{z}^{\prime} \mathbf{K z}$, where $\mathbf{z}$ is a vector with the covariables corresponding to the Legendre polynomials for the trait of interest and $\mathbf{K}$ is estimated covariance matrix $\mathbf{K}_{\mathbf{a}}, \mathbf{K}_{\mathbf{p}}$, or $\mathbf{K}_{\mathbf{h}}$ (Jamrozik et al., 2001). The residual variances for 305-d production and persistency were computed as:

$$
\sigma_{\mathrm{e}, 305 \mathrm{~d}}^{2}=\sum_{\mathrm{i}=5}^{305} \sigma_{\mathrm{e}, \mathrm{i}}^{2} \text { and } \sigma_{\mathrm{e}, \mathrm{pers}}^{2}=\sum_{\mathrm{i}=61}^{305} \sigma_{\mathrm{e}, \mathrm{i}}^{2}+245^{2} \times \sigma_{\mathrm{e}, 60}^{2},
$$

where $\sigma_{\mathrm{e}, \mathrm{i}}^{2}$ is the estimated residual variance at DIM $\mathrm{i}$. Heritabilities were computed as the genetic variance divided by the sum of the genetic, permanent environmental, herd curve, and residual variances. Herd curve variances were also included in the denominator so that the denominator included the total variance of the observations after correction for the fixed effects for both VCE-noHC and VCE-HC, which is required for comparing heritabilities across both models.

\section{RESULTS}

Based on the estimated burn-in for all chains and all parameters, a burn-in of 25,000 iterations was chosen for each chain and each parameter. Table 1 shows the number of Gibbs chains, the total number of iterations in the chains, and the minimum effective chain size across all parameters for VCE-noHC and VCE-HC and for milk, fat, and protein. A large variability in effective chain size was found across all models, traits, and parameters, e.g., for milk production in VCE-HC, the effective chain sizes were between 90 and 327 for the 


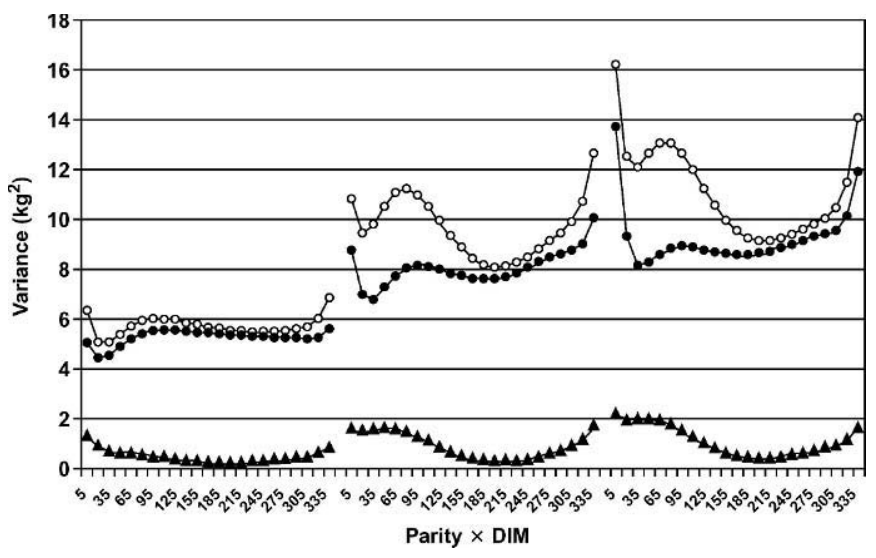

Figure 1. Additive genetic (circles) and herd curve (triangles) variances for daily milk production in parities 1,2 , and 3 estimated using a random regression model without (open) and with (solid) random herd curves.

additive genetic parameters, between 142 and 521 for permanent environmental parameters, between 293 and 4657 for herd curve parameters, and between 1756 and 30,276 for residual variances.

Additive genetic and herd curve variances for daily milk, fat, and protein production estimated in the 2 analyses are shown in Figures 1 to 3 . For all traits in all lactations, the estimated genetic variances were lower for VCE-HC than for VCE-noHC. The differences were largest in the first $100 \mathrm{~d}$ and at the end of the lactation. At maximum, genetic variances for test-day milk, fat, and protein production were reduced 35,26 , and $33 \%$, respectively. Herd curve variances in VCE$\mathrm{HC}$ were low compared with the other variance components, on average $4 \%$ of the phenotypic variance. Herd curve variances were typically U-shaped, with vari-

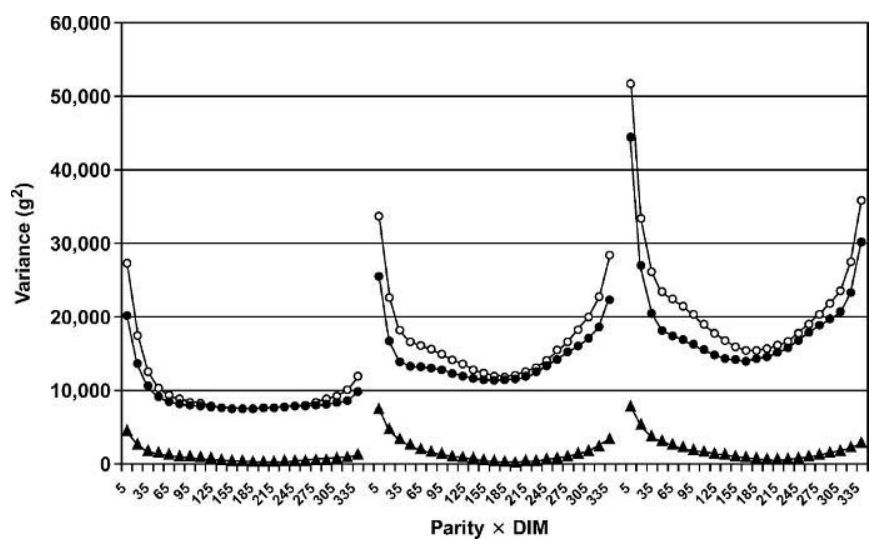

Figure 2. Additive genetic (circles) and herd curve (triangles) variances for daily fat production in parities 1,2 , and 3 estimated using a random regression model without (open) and with (solid) random herd curves.

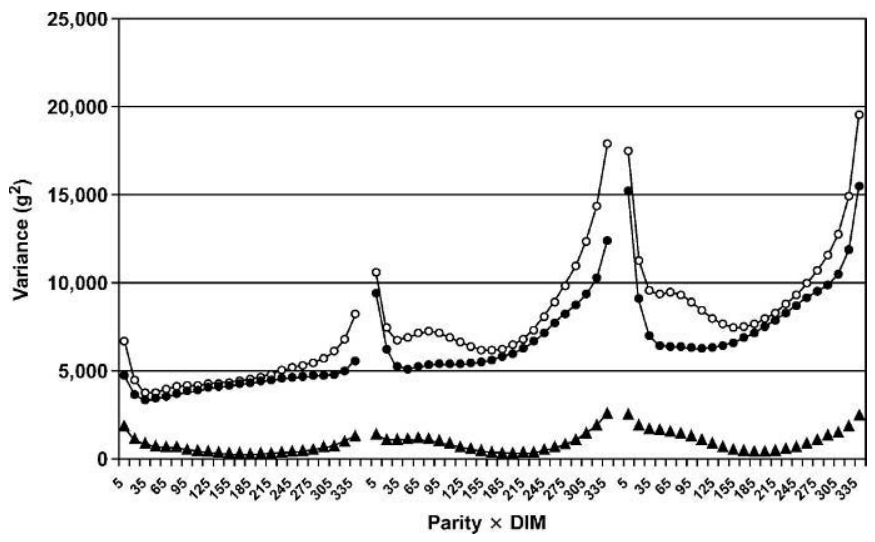

Figure 3. Additive genetic (circles) and herd curve (triangles) variances for daily protein production in parities 1,2 , and 3 estimated using a random regression model without (open) and with (solid) random herd curves.

ances at DIM 5 and 335 being 5 to 15 times larger than in midlactation.

Figure 4 shows the permanent environmental, residual, and phenotypic variances for test-day milk production estimated with VCE-noHC and VCE-HC. For both models, estimated permanent environmental variances were relatively high at the periphery of the lactation, whereas residual variances were highest at the beginning of the lactation and subsequently decreased exponentially. For all 3 traits, permanent environmental, residual, and phenotypic variances hardly differed between VCE-noHC and VCE-HC, and the decrease in genetic variances was almost equal to the herd curve variances in VCE-HC.

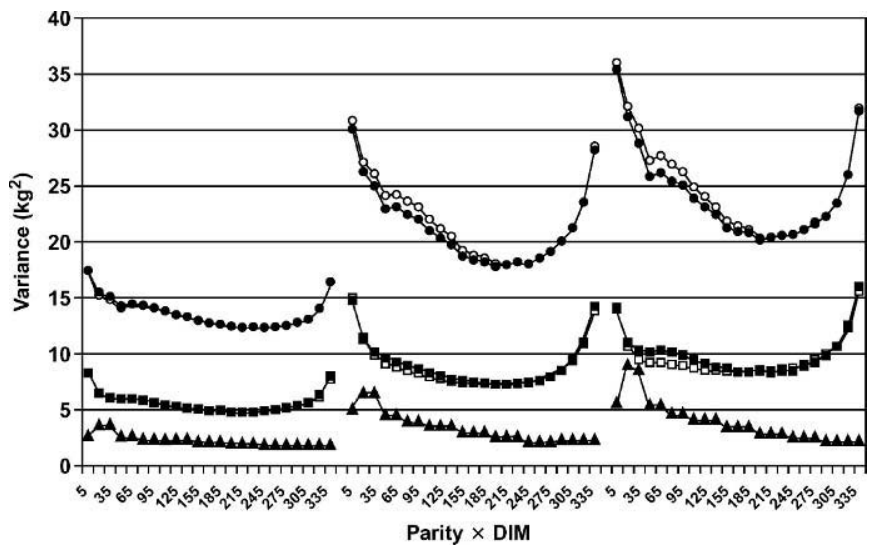

Figure 4. Permanent environmental (squares), residual (triangles), and phenotypic (circles) variances for daily milk production in parities 1,2, and 3 estimated using a random regression model without (open) and with (solid) random herd curves. 


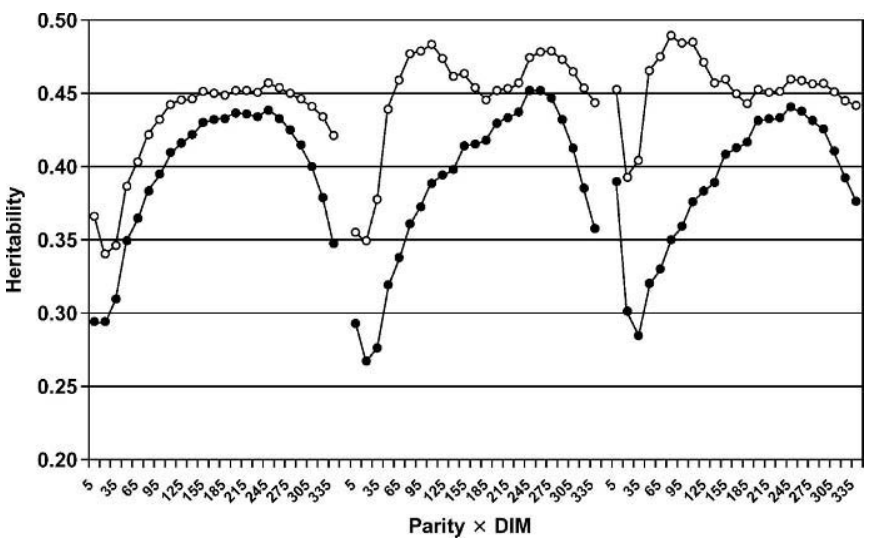

Figure 5. Heritabilities for daily milk production in parities 1, 2, and 3 estimated using a random regression model without (open) and with (solid) random herd curves.

Figures 5 to 7 show the estimated heritabilities of test-day milk, fat, and protein production in lactations 1,2 , and 3 using both models. Heritabilities for daily milk, fat, and protein production were, averaged across all parities and DIM, equal to $0.44,0.38$, and 0.37 for VCE-noHC and 0.39, 0.34, and 0.32 for VCE-HC, respectively. When heritabilities for VCE-HC were computed without the herd curve variance in the denominator, the average heritabilities were $0.41,0.35$, and 0.33 for milk, fat, and protein production, respectively. Testday heritabilities in VCE-noHC and VCE-HC differed most in the first $100 \mathrm{~d}$ and at the end of the lactation, consistently with the decrease in genetic variance. For all traits and all lactations, daily heritabilities in VCE$\mathrm{HC}$ were increasing from beginning of the lactation until around DIM 250 and decreased afterward.

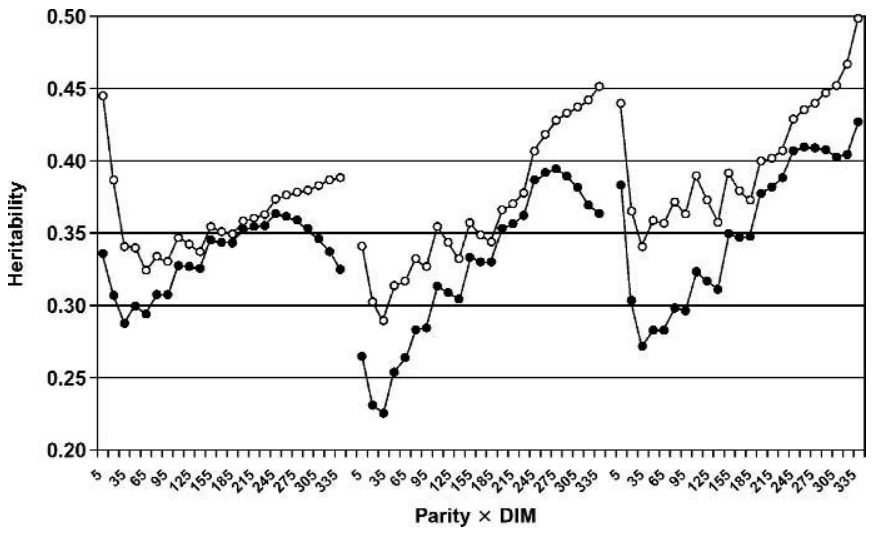

Figure 6. Heritabilities for daily fat production in parities 1, 2, and 3 estimated using a random regression model without (open) and with (solid) random herd curves.

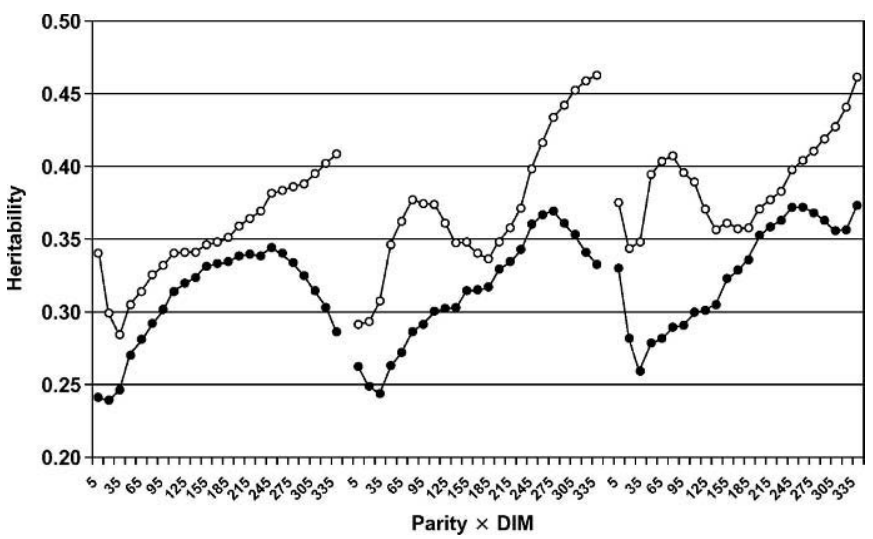

Figure 7. Heritabilities for daily protein production in parities 1, 2 , and 3 estimated using a random regression model without (open) and with (solid) random herd curves.

Table 2 shows the estimated additive genetic, permanent environmental, and herd curve correlations among DIM 5, 50, 170, 305, and 335 within lactations 1, 2, and 3 for test-day milk production. Results for fat and protein production were similar. Genetic correlations within lactation were generally higher for VCE-HC than for VCE-noHC. The largest differences between VCE-noHC and VCE-HC were observed for the genetic correlation between DIM 50 and 335, with increases around $0.25,0.20$, and 0.30 for milk, fat, and protein production, respectively. Genetic correlations for VCE$\mathrm{HC}$ were always positive, whereas for VCE-noHC, some negative correlations were observed in lactations 2 and 3. Permanent environmental correlations within lactation were always positive and were very similar for VCE-noHC and VCE-HC. Herd curve correlations were negative between the beginning and end of the lactation, especially in lactations 2 and 3. Most negative herd curve correlations were observed between DIM 50 and 335 .

Estimated genetic standard deviations and heritabilities for 305-d production were slightly lower for milk, fat, and protein in VCE-HC than in VCE-noHC, especially in lactation 2 and 3 (Table 3 ). Genetic correlations between 305-d production in lactation 1 and 305-d production in lactations 2 and 3 were higher in VCE-HC for all traits. Herd curve variances for overall 305-d production were around $2 \%$ of the phenotypic variance.

Estimated genetic standard deviations for overall milk, fat, and protein persistency were 25,23 , and $30 \%$ lower in VCE-HC, and heritabilities decreased by 0.14 , 0.07 , and 0.14 , respectively (Table 4). Genetic correlations among lactations decreased between 0.05 and 0.16 , with the largest decrease between persistency in lactations 2 and 3. Herd curve variances for overall persistency were $7.5,3.9$, and $7.2 \%$ of the phenotypic 


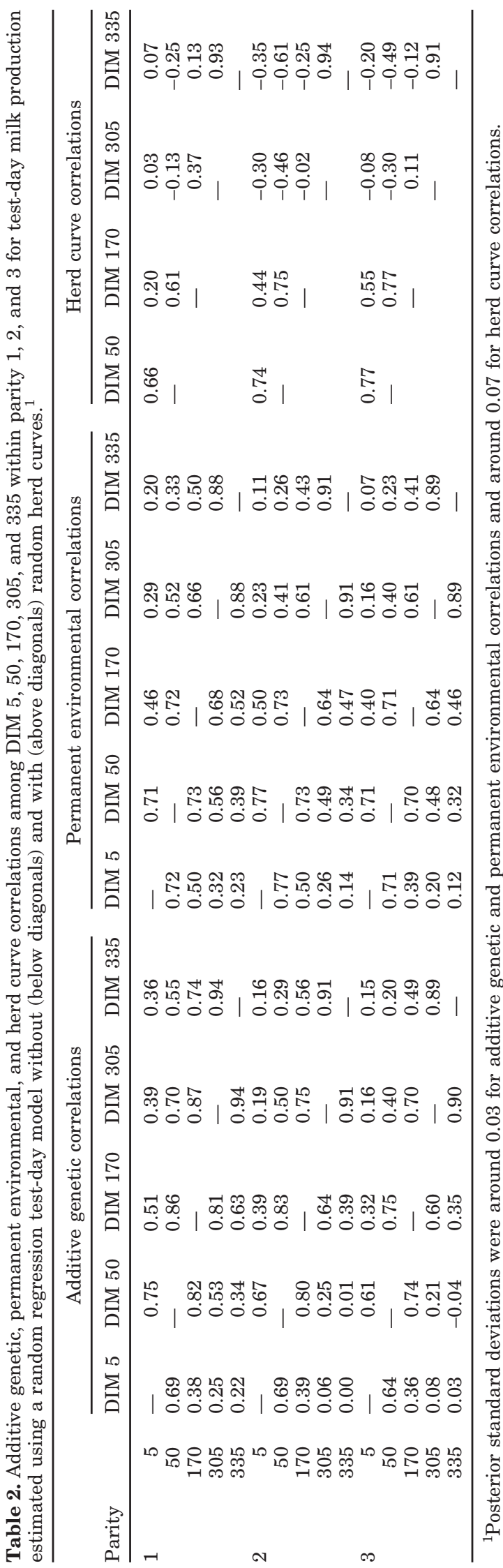

variance for milk, fat, and protein, respectively, and herd curve correlations were around 0.55 between lactation 1 and 2 and lactation 1 and 3 and around 0.90 between lactation 2 and 3 .

\section{DISCUSSION}

Pool (2000) and De Roos and Pool (2001) estimated genetic parameters for test-day milk, fat, and protein production of Dutch dairy cattle using a model comparable with VCE-noHC, but using different data and fixed effects. They found much higher additive genetic and permanent environmental variances at the borders of the lactation trajectory than in VCE-noHC in that study. A reason for this result might be their modeling of the lactation curve, with DIM classes of $1 \mathrm{wk}$ and no interactions between age or season and DIM. The estimated genetic correlation structure, however, was very comparable with VCE-noHC in this study.

Heritabilities for test-day production were comparable with those estimated by Jamrozik et al. (2001) and Samoré et al. (2002), who also used a random regression model, but were higher than those in Emmerling et al. (2002), Gengler et al. (2001), and Lidauer et al. (2000), who used a multi-trait model with different lactation stages treated as different traits. Janss and De Jong (1999) also found relatively high heritabilities for milk, fat, and protein production in Dutch dairy cattle using a repeatability lactation animal model.

The observed differences between VCE-noHC and VCE-HC for first lactation milk production were similar to those observed by Jamrozik et al. (2001) when herd $\times$ year $\times$ season was added as a fixed effect to the second stage of the hierarchical model, i.e., the herd curves reduced estimated genetic and permanent environmental variances and heritabilities at the lactation borders and increased genetic correlations within lactation. Their model, including the fixed herd curves, gave almost identical genetic, permanent environmental, and residual variances; heritabilities; and genetic correlations as VCE-HC. At the end of the lactation, however, the high genetic and permanent environmental variances that were found in VCE-noHC were not as apparent in their model without the fixed herd curves. This result might have been due to the use of Legendre polynomials in our study (instead of the Wilmink function), which have more flexibility at the end of the lactation. Samoré et al. (2002) also used the Wilmink function and found a sharp increase in genetic variance at the beginning of lactation and not as much at the end.

Estimated genetic correlations between extreme DIM within lactation of VCE-HC were more consistent with studies using indirect methods, where parts of the lactation are modeled as different traits, than those obtained 
Table 3. Genetic standard deviations $\left(\sigma_{\mathrm{a}}\right)$, heritabilities $\left(\mathrm{h}^{2}\right)$, and genetic correlations $\left(\mathrm{r}_{\mathrm{g}}\right)$ for 305-d milk, fat, and protein production in lactations $1,2,3$, and overall ${ }^{1}$ estimated using a random regression test-day model without (VCE-noHC) and with (VCE-HC) random herd curves. ${ }^{2}$

\begin{tabular}{|c|c|c|c|c|c|c|c|c|c|c|c|}
\hline \multirow[b]{3}{*}{ Trait } & \multirow[b]{3}{*}{ Lactation } & \multicolumn{5}{|c|}{ VCE-noHC } & \multicolumn{5}{|c|}{ VCE-HC } \\
\hline & & \multirow[b]{2}{*}{$\sigma_{\mathrm{a}}(\mathrm{kg})$} & \multirow[b]{2}{*}{$\mathrm{h}^{2}$} & \multicolumn{3}{|c|}{$\mathrm{r}_{\mathrm{g}}$} & \multirow[b]{2}{*}{$\sigma_{\mathrm{a}}(\mathrm{kg})$} & \multirow[b]{2}{*}{$\mathrm{h}^{2}$} & \multicolumn{3}{|c|}{$r_{g}$} \\
\hline & & & & 2 & 3 & Overall & & & 2 & 3 & Overal \\
\hline \multirow[t]{4}{*}{ Milk } & 1 & 655.9 & 0.53 & \multirow[t]{4}{*}{0.82} & 0.76 & 0.92 & 651.9 & 0.51 & \multirow[t]{4}{*}{0.85} & 0.80 & 0.94 \\
\hline & 2 & 811.9 & 0.53 & & 0.88 & 0.96 & 767.2 & 0.49 & & 0.87 & 0.96 \\
\hline & 3 & 851.9 & 0.54 & & & 0.93 & 791.3 & 0.47 & & & 0.93 \\
\hline & Overall & 712.5 & 0.61 & & & & 687.1 & 0.58 & & & \\
\hline \multirow[t]{4}{*}{ Fat } & 1 & 25.8 & 0.51 & \multirow[t]{4}{*}{0.83} & 0.76 & 0.92 & 25.9 & 0.50 & \multirow[t]{4}{*}{0.85} & 0.79 & 0.94 \\
\hline & 2 & 31.6 & 0.50 & & 0.87 & 0.96 & 30.9 & 0.48 & & 0.87 & 0.96 \\
\hline & 3 & 35.6 & 0.54 & & & 0.93 & 34.0 & 0.50 & & & 0.93 \\
\hline & Overall & 28.4 & 0.59 & & & & 28.0 & 0.58 & & & \\
\hline \multirow[t]{4}{*}{ Protein } & 1 & 18.3 & 0.46 & \multirow[t]{4}{*}{0.79} & 0.70 & 0.90 & 18.2 & 0.45 & \multirow[t]{4}{*}{0.83} & 0.75 & 0.93 \\
\hline & 2 & 21.9 & 0.45 & & 0.87 & 0.96 & 21.2 & 0.43 & & 0.86 & 0.96 \\
\hline & 3 & 23.9 & 0.47 & & & 0.91 & 22.7 & 0.43 & & & 0.92 \\
\hline & Overall & 19.3 & 0.52 & & & & 19.0 & 0.51 & & & \\
\hline
\end{tabular}

${ }^{1}$ Overall represents lactations 1,2 , and 3 combined with weights $0.41,0.33$, and 0.26 .

${ }^{2}$ Posterior standard deviations of heritabilities and genetic correlations were around 0.02 .

with VCE-noHC. For example, genetic correlations for milk production in lactation 1 between beginning and end of the lactation, that were estimated with indirect methods were 0.49 (DIM 10 and 310; Lidauer et al., 2000), 0.40 (DIM 14 and 311; Emmerling et al., 2002), 0.50 (DIM 5 and 305; Gengler et al., 2001), 0.38 (DIM 5 and 305; Kettunen et al., 2000), 0.53 (DIM 12 and 315; Mäntysaari, 1999), whereas the genetic correlation for first lactation milk production between DIM 5 and 305 was 0.25 in VCE-noHC and 0.39 in VCE-HC.

In general, the estimated variance components in VCE-HC are more consistent with other studies and give more reasonable results than those in VCE-noHC. This does not necessarily mean, however, that this model is also better. More formal comparisons, e.g., using Bayes factors or the predictability of omitted data, may be helpful to choose the best method by a more objective criterion.

The variance of the random herd curves was highest at the borders of the lactation and negligible in the midlactation, which is in accordance with Gengler et al. (2001). The negative herd curve correlations between beginning and end of the lactation, the U-shaped variances across DIM, and the low herd curve variance for 305-d production indicate that the herd curves model the differences in persistency across herds, whereas differences in level of production across herds are modeled with the fixed HTD effect. Differences in persis-

Table 4. Genetic standard deviations $\left(\sigma_{\mathrm{a}}\right)$, heritabilities $\left(\mathrm{h}^{2}\right)$, and genetic correlations $\left(\mathrm{r}_{\mathrm{g}}\right)$ for milk, fat, and protein persistency in lactations $1,2,3$, and overall ${ }^{1}$ estimated using a random regression test-day model without (VCE-noHC) and with (VCE-HC) random herd curves. ${ }^{2}$

\begin{tabular}{|c|c|c|c|c|c|c|c|c|c|c|c|}
\hline \multirow[b]{3}{*}{ Trait } & \multirow[b]{3}{*}{ Lactation } & \multicolumn{5}{|c|}{ VCE-noHC } & \multicolumn{5}{|c|}{ VCE-HC } \\
\hline & & \multirow[b]{2}{*}{$\sigma_{\mathrm{a}}(\mathrm{kg})$} & \multirow[b]{2}{*}{$h^{2}$} & \multicolumn{3}{|c|}{$r_{g}$} & \multirow[b]{2}{*}{$\sigma_{\mathrm{a}}(\mathrm{kg})$} & \multirow[b]{2}{*}{$\mathrm{h}^{2}$} & \multicolumn{3}{|c|}{$r_{g}$} \\
\hline & & & & 2 & 3 & Overall & & & 2 & 3 & Overall \\
\hline \multirow[t]{4}{*}{ Milk } & 1 & 296.3 & 0.25 & 0.58 & 0.57 & 0.80 & 239.4 & 0.16 & 0.52 & 0.51 & 0.78 \\
\hline & 2 & 464.1 & 0.33 & & 0.81 & 0.92 & 345.2 & 0.19 & & 0.69 & 0.88 \\
\hline & 3 & 542.6 & 0.36 & & & 0.91 & 427.4 & 0.23 & & & 0.88 \\
\hline & Overall & 366.8 & 0.32 & & & & 274.3 & 0.18 & & & \\
\hline \multirow[t]{4}{*}{ Fat } & 1 & 13.4 & 0.18 & 0.55 & 0.51 & 0.78 & 10.6 & 0.11 & 0.49 & 0.46 & 0.76 \\
\hline & 2 & 20.3 & 0.20 & & 0.76 & 0.91 & 15.8 & 0.13 & & 0.62 & 0.86 \\
\hline & 3 & 24.8 & 0.24 & & & 0.89 & 20.7 & 0.17 & & & 0.86 \\
\hline & Overall & 16.1 & 0.18 & & & & 12.4 & 0.11 & & & \\
\hline \multirow[t]{4}{*}{ Protein } & 1 & 9.6 & 0.22 & 0.61 & 0.60 & 0.82 & 6.9 & 0.11 & 0.50 & 0.46 & 0.76 \\
\hline & 2 & 14.3 & 0.28 & & 0.76 & 0.91 & 10.4 & 0.15 & & 0.60 & 0.86 \\
\hline & 3 & 17.2 & 0.33 & & & 0.90 & 13.5 & 0.21 & & & 0.85 \\
\hline & Overall & 11.6 & 0.27 & & & & 8.1 & 0.14 & & & \\
\hline
\end{tabular}

${ }^{1}$ Overall represents lactations 1,2 , and 3 combined with weights $0.41,0.33$, and 0.26 .

${ }^{2}$ Posterior standard deviations were around 0.02 for heritabilities and around 0.05 for genetic correlations. 
tency across herds may have several causes, e.g., single group feeding systems may be nutritionally poor for fresh cows, but too rich for cows at the end of lactation, causing a higher persistency, whereas herds that feed cows according to their production levels may have cows with a higher peak production and a lower production at the end of the lactation.

In random regression models without fixed or random herd curves, the herd effect on the lactation curve should theoretically be modeled by the permanent environmental regression curves and not by the genetic curves. However, this study as well as those of Jamrozik et al. (2001) and Gengler et al. (2001) clearly shows that estimated genetic variances at the periphery of the lactation are increased if the herd curves are not modeled separately. One explanation may be that cows and their dams are very often milked in the same herds, which may give animal models difficulties in separating herd and genetic effects. It should also be determined whether other effects that affect the shape of the lactation curve, such as gestation stage (Olori et al., 1997), have a similar effect on genetic variances and correlations if they are included in the parameter estimation.

Heritabilities of overall 305-d production in both models were relatively high compared with heritabilities of test-day production or heritabilities for 305-d production estimated with a repeatability lactation model (Janss and De Jong, 1999). These heritabilities should, however, be interpreted with care, as 305-d production is not actually recorded. The heritability of overall 305$\mathrm{d}$ production in a test-day model represents the ratio between the genetic and phenotypic variance when a cow would be recorded on each day of each lactation. Because residuals between these records are assumed uncorrelated and permanent environmental correlations between records on different parity or DIM are much lower than additive genetic correlations, the additive genetic variance for overall 305 -d production is relatively high, whereas residual and permanent environmental variances are partially diluted. This results in higher heritabilities for overall 305-d production compared with test-day production. Furthermore, in reality, cows are not recorded on each day of each lactation, which results in lower heritabilities for overall 305-d production in repeatability lactation models.

The inclusion of random herd curves severely reduced the estimated genetic variances and heritabilities for persistency, possibly because herd curve effects are partly modeled by the genetic curves when they are not modeled separately. Heritabilities for persistency in VCE-HC were close to those of Jakobsen et al. (2002), who used a similar definition of persistency in combination with a random regression model.
In this study, herd curves were modeled separately for every lactation, which means that differences across herds for progress in production from lactation 2 to lactation 3 were also modeled with the random herd curves effect. For example, Herd A may have relatively high-producing heifers but a poor progress in production over lactations, whereas Herd B may have heifers that start at a lower level of production but show a large progress in production over lactations. When this interaction between herd and parity is not modeled separately, as in VCE-noHC, it may be modeled by the genetic effect, causing lower genetic correlations between the lactations. Another option to circumvent this is to model the HTD effect as HTD $\times$ parity.

\section{CONCLUSIONS}

The inclusion of random herd curves in a random regression model for test-day milk, fat, and protein production reduced estimated genetic variances in the first $100 \mathrm{~d}$ and at the end of the lactation by up to $35 \%$ and reduced test-day heritabilities by 0.05 on average. Subsequently, heritabilities of persistency were up to 0.14 lower, and genetic standard deviations for persistency were up to $30 \%$ lower, when the random herd curves were added to the model. Genetic correlations between DIM 50 and 335 increased by approximately 0.25 and were more consistent with studies where lactation stages are analyzed as different traits. Genetic correlations for 305-d production across lactations increased. Herd curve variances were highest at the borders of the lactation but relatively small compared with the phenotypic variance.

It is recommended that herd curves be included in random regression models for the analysis of test-day milk production traits in dairy cattle. As of November 2002 , the genetic evaluation for production traits in The Netherlands and Flanders is based on a random regression test-day model including random herd curves.

\section{ACKNOWLEDGMENT}

We thank Erwin Koenen for the review of an earlier version of this manuscript.

\section{REFERENCES}

De Roos, A. P. W., A. G. F. Harbers, and G. De Jong. 2001. Random regression test-day model in The Netherlands. Interbull Bull. 27:155-158.

De Roos, A. P. W., and M. H. Pool. 2001. Test-day model parameters for dairy cattle in The Netherlands. Proc. 52nd Annu. Mtg. EAAP, Budapest, Hungary 7:11.

Emmerling, R., M. Lidauer, and E. A. Mäntysaari. 2002. Multiple lactation random regression test-day model for Simmental and Brown Swiss in Germany and Austria. Interbull Bull. 29:111-117. 
Gengler, N., A. Tijani, G. R. Wiggans, and J. C. Philpot. 2001. Indirect estimation of (co)variance functions for test-day yields during first and second lactations in the United States. J. Dairy Sci. 84(Feb.). Online. Available: http://www.adsa.org/jds/jds9296E/ jds9296.html. Accessed Oct. 28, 2002.

Gengler, N., and G. R. Wiggans. 2001. Variance of effects of lactation stage within herd by herd yield. J. Dairy Sci. 84(Suppl. 1):216. (Abstr.)

Guo, Z., and L. R. Schaeffer. 2002. Random regression submodel comparison. Proc. 7th World Congr. Genet. Appl. Livest. Prod., Montpellier, France 32:525-528.

Interbull. 2003. Evaluation summaries for production traits. Online. Available: http://www-interbull.slu.se/eval/framesida-prod.htm. Accessed Oct. 2, 2003.

Jakobsen, J. H., P. Madsen, J. Jensen, J. Pedersen, L. G. Christensen, and D. A. Sorensen. 2002. Genetic parameters for milk production and persistency for Danish Holsteins estimated in random regression models using REML. J. Dairy Sci. 85:1607-1616.

Jamrozik, J., D. Gianola, and L. R. Schaeffer. 2001. Bayesian estimation of genetic parameters for test day records in dairy cattle using linear hierarchical models. Livest. Prod. Sci. 71:223-240.

Jamrozik, J., and L. R. Schaeffer. 2002. Bayesian comparison of random regression models for test-day yields in dairy cattle. Proc. 7th World Congr. Genet. Appl. Livest. Prod., Montpellier, France 29:47-50.

Jamrozik, J., L. R. Schaeffer, and J. C. M. Dekkers. 1997a. Genetic evaluation of dairy cattle using test day yields and random regression model. J. Dairy Sci. 80:1217-1226.

Jamrozik, J., L. R. Schaeffer, and F. Grignola. 1998. Genetic parameters for production traits and somatic cell score of Canadian Holsteins with multiple trait random regression model. Proc. 6th World Congr. Genet. Appl. Livest. Prod., Armidale, Australia 23:303-306

Jamrozik, J., L. R. Schaeffer, Z. Liu, and G. Jansen. 1997b. Multiple trait random regression test day model for production traits. Interbull Bull. 16:43-47.

Janss, L. L. G., and G. De Jong. 1999. MCMC based estimation of variance components in a very large dairy cattle data set. Interbull Bull. 20:63-68.

Kettunen, A., E. A. Mäntysaari, and J. Pösö. 2000. Estimation of genetic parameters for daily milk yield of primiparous Ayrshire cows by random regression test-day models. Livest. Prod. Sci. 66:251-261.
Kirkpatrick, M., D. Lofsvold, and M. Bulmer. 1990. Analysis of the inheritance, selection and evolution of growth trajectories. Genetics 124:979-993.

Lidauer, M., E. A. Mäntysaari, I. Strandén, and J. Pösö. 2000. Multiple-trait random regression model for all lactations. Interbull Bull. 25:81-86.

Mäntysaari, E. A. 1999. Derivation of multiple trait reduced rank random regression $(\mathrm{RR})$ model for the first lactation test day records of milk, protein and fat. Proc. 50th Annu. Mtg. EAAP, Zurich, Switzerland 5:26.

NRS. 2003. E-7. Breeding value estimation of milk production traits with test-day model. Online. Available: http://www.cr-delta.nl/ english/breedingvalues/FWS-Ehfdst.jsp. Accessed Oct. 2, 2003.

Olori, V. E., S. Brotherstone, W. G. Hill, and B. J. McGuirk. 1997. Effect of gestation stage on milk yield and composition in Holstein Friesian dairy cattle. Livest. Prod. Sci. 52:167-176.

Olori, V. E., W. G. Hill, B. J. McGuirk, and S. Brotherstone. 1999. Estimating variance components for test day milk records by restricted maximum likelihood with a random regression animal model. Livest. Prod. Sci. 61:53-63.

Pool, M. H. 2000. Test-day models. Breeding value estimation based on individual test-day records. Ph.D. Diss., Wageningen Institute of Animal Sciences, Wageningen, The Netherlands.

Pool, M. H., L. L. G. Janss, and T. H. E. Meuwissen. 2000. Genetic parameters of Legendre polynomials for first parity lactation curves. J. Dairy Sci. 83:2640-2649.

Pool, M. H., and T. H. E. Meuwissen. 2000. Reduction of the number of parameters needed for a polynomial random regression testday model. Livest. Prod. Sci. 64:133-145.

Rekaya, R., M. J. Carabaño, and M. A. Toro. 1999. Use of test day yields for the genetic evaluation of production traits in HolsteinFriesian cattle. Livest. Prod. Sci. 57:203-217.

Samoré, A. B., P. Boettcher, J. Jamrozik, A. Bagnato, and A. F. Groen 2002. Genetic parameters for production traits and somatic cell scores estimated with a multiple trait random regression model in Italian Holsteins. Proc. 7th World Congr. Genet. Appl. Livest. Prod., Montpellier, France 29:63-66.

Van der Werf, J. H. J., M. E. Goddard, and K. Meyer. 1998. The use of covariance functions and random regressions for genetic evaluation of milk production based on test day records. J. Dairy Sci. 81:3300-3308.

Van Kaam, J. B. C. H. M. 1998. Gibanal 2.9. Analyzing Program for Markov Chain Monte Carlo Sequences. Dep. Anim. Sci., Wageningen Agricultural University, Wageningen, The Netherlands. 